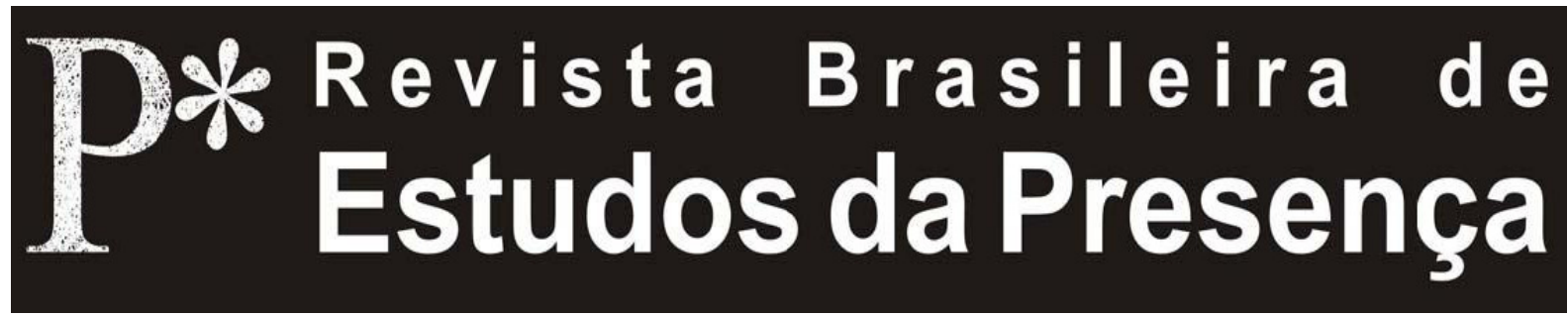

DOI - http://dx.doi.org/10.1590/2237-266036249

ISSN 2237-2660

\title{
Um Diärio de Gênese: L'Atelier Volant de Valère Novarina
}

\author{
Jean-Marie Thomasseau \\ Université Vincennes Saint Denis Paris 8 - Saint Denis, França
}

RESUMO - Um Diário de Gênese: L'Atelier Volant de Valère Novarina ${ }^{1}$ - Este texto descreve e analisa o diário do escritor-dramaturgo Valère Novarina. Explora-se as anotaçôes como registros do processo criativo que deu surgimento à peça L'Atelier Volant e descrevese as inquietaçóes e problematizaçóes do autor em relação à primeira encenação. A partir da noção cunhada por Novarina de encenação, o texto mostra a inadequação das ideias do dramaturgo em relação ao teatro de seu tempo e como a encenaçáo teve papel fundamental no trabalho dramatúrgico do autor.

Palavras-chave: Teatro. Texto Teatral. Genética Teatral. Valère Novarina. Processos de Criaçáo.

ABSTRACT - A Diary of Genesis: L'Atelier Volant by Valère Novarina - This paper describes and analyses the diary of the writer and playwright Valère Novarina. It explores his notes as records of the creative process that originated the play L'Atelier Volant and describes the concerns and problematisations of the author with regard to the first staging the play. Based on Novarina's notion of staging, the text shows the inadequacy of the playwright's ideas in relation to the theatre of his time and the way this staging played a fundamental role in the author's dramaturgical work.

Keywords: Theatre. Theatrical Text. Theatrical Genetics. Valère Novarina. Creative Processes.

RÉSUMÉ - Un Journal de Genèse: L'Atelier Volant de Valère Novarina - Ce texte propose une description et une analyse du journal de l'écrivain dramaturge Valère Novarina. Il explore ses annotations en tant que traces du processus de création qui a donné naissance à la pièce L'Atelier Volant, faisant ressortir les inquiétudes et les questionnements du dramaturge à propos de sa première mise en scène. Partant de la notion de mise en scène propre à Novarina, le texte montre l'inadéquation de ses idées par rapport au théâtre de son époque et le rôle fondamental de la mise en scène dans le travail dramaturgique de l'auteur. Mots-clés: Théâtre. Texte Théâtral. Génétique Théâtrale. Valère Novarina. Processus de Création. 
"A Balsa da Medusa! Era ao mesmo tempo Verdun e a Balsa da Medusa! Com essa primeira peça, eu descobri os aspectos mais penosos, às vezes muito desagradáveis, da vida teatral, de uma só vez, na dor, as irritaçóes, os afrontamentos. A partir dali, eu nunca mais precisei enfrentar tal série de desventuras. Eu fui, entáo, iniciado". Foi o que me confiou Valère Novarina, me mostrando, no seu ateliê, num dia de junho de 2008 , o registro no qual estava escrito de próprio punho um conjunto de breves anotaçôes ligadas a essas circunstâncias fundadoras. Eu sentia, durante uma primeira leitura superficial do manuscrito, o sentimento de ser confrontado a um documento essencial para apreender náo somente os desafios de uma primeira obra, mas o estabelecimento de uma poética teatral que estava por vir, e, em grande parte, se descobrindo ${ }^{2}$. De natureza compósita, às vezes com longas interrupçóes, fornecendo dados esparsos e fragmentados, esse grande caderno preto que participa ao mesmo tempo do diário de criação, do processo verbal e do manifesto, é difícil de ser classificado nas categorias habituais dos manuscritos teatrais ${ }^{3}$. As quarenta e oito primeiras páginas desse documento, das 106 redigidas, dedicadas a uma posterior gestação de outras obras, são destinadas à L'Atelier Volant. É essencialmente dessas páginas que a presente análise tratará: um conjunto de curtas observaçôes de natureza diversificada que acompanham primeiro a gravaçáo da peça para o rádio, para depois seguir de perto sua primeira encenação, observada alternadamente do interior e do exterior.

De acordo com Novarina, o texto de L'Atelier Volant começou a ser escrito em fevereiro de 1968 e seu primeiro título era, ao que parece, Monnaie de Bouc 4 . Duas versóes, cuja segunda foi retrabalhada, foram logo enviadas a Roland Barthes, que apreciou a mistura de dureza e humor ${ }^{5}$. Ao contrastar com a seriedade brechtiana do teatro da época, L'Atelier Volant dá, também, o sopro inicial e decisivo de uma série de experiências inovadoras no âmbito da escrita e do encenamento de peças. $\mathrm{O}$ emprego do neologismo encenamento, a partir da segunda página do Diário, datada de 28 de janeiro de 1972, testemunha a impropriedade, para Novarina, dos termos familiares de encenação ou de mise en voix e mostra o espírito inovador que há nesse registro, começado em janeiro de 1972 . O conjunto revela de antemão um escritor consciente das suas exigências e que, desde muito cedo, reúne com rigor a estrutura de uma obra em construção. Esse Diário testemunha também os tempos fortes de um texto escrito ${ }^{7}$ para 
testar a sua implementação, primeiro no rádio, depois no palco, e os retornos ofensivos e corretivos dessa dupla experimentação antes de culminar no texto impresso definitivo, entregue ao leitor em $1989^{8}$.

Por outro lado, o autor, essencialmente, viu L'Atelier Volant escapar das suas garras, já que Jean-Pierre Sarrazac, responsável pela encenação, queria assumir a total responsabilidade da peça. O Diário acompanha, assim, os percalços de um afrontamento ao mesmo tempo latente e aberto entre o autor de um primeiro texto e seu primeiro diretor. De acordo com as circunstâncias, ou Novarina entra como um viajante clandestino no laboratório in vivo da gestaçáo de L'Atelier Volant, ou ele observa de fora. Essa posição insustentável vai gerar outro texto, que se tornou uma referência: La Lettre aux acteurs ${ }^{9}$, cuja primeira versão foi entregue dividida em duas publicaçôes, sob forma de fotocópias, aos atores de L'Atelier Volant, na saída de um ensaio.

A última justificativa da nossa tentativa de explorar essas páginas nos foi revelada pelo próprio Novarina, em sua anotação datada de 10 de outubro de 1978:

É isto, escreve ele, que deveria ser feito em Marselha ou em outro lugar... Uma espécie de exposição total de todo o seu trabalho: diversos aparelhos difundindo as açōes, as gravaçôes... / Com manuscritos na parede, todas as anotaçôes; o mural... Uma exposição Novarina.

No dia 16 de outubro de 1978, ele precisa: "eu precisaria de um lugar livre, um ateliê onde se possa apresentar as coisas em andamento [...]"10. Em suma, um sonho teatral que, de início, seria uma genética teatralizada.

\section{O Ignorado e o Nunca Ouvido}

$\mathrm{Na}$ lógica dessa intervenção sonhada em forma de "performance, o título, L'Atelier Volant se enriquece de uma nova conotação. Quanto ao Diário, não é por acaso que ele começa por uma lista de atores, um projeto ideal de elenco para a passagem da peça no rádio. De antemão, afirma-se nela, como será o caso ao longo da obra que está por vir, o papel preponderante do ator ao mesmo tempo porta-voz e modelador da matéria sonora da linguagem. A encenação radiofônica da peça amplifica, ainda, a dimensão anunciadora de um teatro das palavras que não pode, sui generis, abandonar sua dimensão subversiva, como enfatiza uma observação de 24 de janeiro de 1972: "nós estamos desmascarados como indivíduos que querem 'perturbar a 
arte radiofônica". Essa nova maneira, nas ondas do rádio, de dar corpo à linguagem e de não se submeter aos códigos ultrapassados da dramaturgia e da dicçáo radiofônica será, durante o tempo da preparação do programa, fonte de tensôes com o diretor Georges Peyrou.

O "contraste das vozes" (27 de janeiro), o ritmo da elocução, a tessitura vocal de cada ator, nas condiçóes da gravação, agem, para Novarina, como reveladores de modificaçóes necessárias ao texto. As primeiras horas de ensaio em um "trabalho em carne viva" (27 de janeiro) fazem, ainda, advir a necessidade de ajustes, primeiro da pontuação: "toda pontuação precisa ser revista" (26 de janeiro); "refazer toda a pontuação do início" (29 de janeiro); "rever bem a grafia e a pontuação da cena do limpador de chaminés" (29 de janeiro). Essa maneira de recortar o texto e de costurá-lo novamente de outra forma não é um ato supérfluo: ela faz parte da necessidade de seguir estritamente os imperativos rítmicos dos corpos condutores da linguagem até preconizar: "o próprio texto escrevê-lo + foneticamente, mesmo que seja necessário colocar uma tradução ao lado" (29 de janeiro). Mais tarde, durante os ensaios da encenação de Jean-Pierre Sarrazac, encontraremos até mesmo a anotaçáo seguinte: "metade da pontuação está em excesso" (27 de novembro de 1973).

Essa constatação inicial leva Novarina a construir um opus incertum, um conjunto harmonioso de elementos compostos que "pedem técnicas de interpretação muito diferentes". Ele se explica em uma longa anotaçáo, datada de 31 de janeiro de 1972:

[...] começar a separar bem os momentos, as situaçóes, as tarefas a serem realizadas na peça (nenhum quadro deve ser interpretado da mesma maneira). Ver em seguida como os tons diferentes coexistem, travam uma luta dentro de uma mesma réplica, de um monólogo. Mas não se encontra esse estilo de interpretaçáo imediatamente. É preciso primeiro interpretar bem os diferentes momentos da peça.

O eixo em torno do qual gira o dispositivo se define em funçáo do jogo dos atores, como a continuaçáo do raciocínio define:

[...] a nova divisão dos quadros que precisa ser feita, as pontuaçóes e a encenação e o dispositivo que deve ser utilizado, devem ser feitos em função do jogo dos atores. Marcar os momentos nos quais tudo está confuso. Colocar pontos de referência no chão e sobre o papel (31 de janeiro).

Pontos de referência no chão para a rádio, está aí algo que pode surpreender. Mas a peça radiofônica já participa, no imaginário 
novariniano, da futura construção cênica que virá, da qual é indissociável, assim como o livro, que também precisa de marcadores. Ela permite, ainda, entrar, segundo uma expressão familiar ao autor, "em assonância" com o texto: a descoberta vocal e a escuta, o tratamento plástico do texto, tornam-se passagens obrigatórias para a escrita, o que será formalizado mais tarde em Teatro dos ouvidos. $\mathrm{Na}$ rádio, o espaço lúdico se fecha inteiramente sobre as ressonâncias do invólucro sonoro, no qual a materialidade da linguagem toma forma sem a presença corporal dos atores, mas com a sua expressão mais palpável: a voz. $\mathrm{O}$ fato de essa primeira obra ter passado primeiro por essa porta estreita explica, talvez, os futuros rituais da escrita novariniana e suas exigências: "de modo geral o texto não está muito mal!" repara ele, em 27 de janeiro de 1972. "Não será preciso cortar nada antes de escutá-lo ser dito ${ }^{11}$. Conseguir primeiro que todo o texto seja interpretado". Dessa forma, quase de maneira inconsciente ao autor, se instaura um ato programático do qual ele não se desviará mais: todo texto "nunca ouvido" deverá ser aperfeiçoado pela força sugestiva da mastigaçáo das palavras, que desvenda o que ainda é ignorado. Tal procedimento explica em parte a preferência de Novarina pela leitura em voz-alta, mediaçáo decisiva durante a qual o autor, transformado em ator do seu próprio texto, dá o toque final à escrita, a rubrica, confere-lhe o seu último impacto ${ }^{12}$.

Depois de longos meses de demora de Lucien Attoun e de Marcel Maréchal, a quem Marcel Bozonnet havia revelado a existência da peça ${ }^{13}$, depois de uma sequência de atrasos acumulados, táticas dilatórias por conta de uma censura disfarçada sob o pretexto de referendo, os imbróglios do que Novarina chama de "o tenebroso caso Sallebert" ${ }^{14}$, L'Atelier Volant é, enfim, transmitido na rádio FranceCulture às $21 \mathrm{~h} 50 \mathrm{~m}$ do dia 3 de junho de $1972^{15}$.

\section{Os Atos do Encenamento}

No dia 6 de abril de 1972, Novarina faz uma anotação sobre um telefonema de Martin-Barbaz (assistente de Planchon), que deseja montar a peça em Avignon; Marcel Maréchal, em 15 de abril, reformula seu projeto de montar a peça, pedindo um prazo; em 28 de outubro, Arlette Reinerg, companheira de Roland Dubillard, fala à Novarina sobre o seu desejo de encenar L'Atelier Volant. Em 3 de novembro, depois de um almoço com Bernand Dort, que o adverte sobre Reinerg, Novarina anota: "faltaria ver Jourdheuil, Regnault, 
Sarrazac, Blin”. Em 16 de dezembro, ele observa que o projeto de Reinerg arrasta-se por falta de subvenção e que Maréchal, independentemente disso, poderia montá-la em Lyon e, no dia 16 de janeiro de 1973, que Debauche quase conseguiu programar uma apresentação. No entanto, uma leitura na casa de Reinerg em 19 de março parece dar corpo ao projeto, mas alguns conflitos ásperos surgem. Depois de muitas idas e vindas de todos os participantes, é, finalmente, Jean-Pierre Sarrazac quem, entre 13 e 23 de abril, decide se responsabilizar pela encenação.

Dessa vez a peça sai do perímetro restrito da rádio e das leituras públicas para encontrar outra amplitude em um palco e encontrar também outras dificuldades, em particular a de ver se dissociarem as escolhas estéticas do autor e do diretor. Uma anotação do dia 23 de abril é explícita sobre esse assunto: "[...] o trabalho sobre L'Atelier Volant começa bem. Agora fica bem claro que eu náo participarei em nada do espetáculo (acabo de ter sido mandado pastar depois de uma sugestão sobre as bonecas)".

Novarina deseja, entáo, uma espécie de modus vivendi e ele traça, na mesma data, um programa que coloca em evidência os valores fundadores do seu teatro: a arte do ator e o ritmo: "[...] pensamos em continuar com duas zonas de intervenção: aulas individuais aos atores (percurso dos personagens) e avaliaçôes semanais sobre o ritmo geral. /E talvez tenhamos que nos comunicar por escrito! Enviar anotaçóes sem resposta como uma espécie de outro texto de desenvolvimento das indicaçôes cênicas" (13 de outubro).

Os ensaios começam no dia 12 de novembro, com uma leitura da peça feita pelo próprio Novarina, mas ele é informado, no dia 14, que ele é persona non grata nos ensaios: "deixei Jean-Pierre, que não faz questão de me ver nos ensaios". Instaura-se, então, um jogo de pique-esconde e, sobretudo, o descontentamento "por estar mais uma vez separado dos atores. [...] O que eu queria era simplesmente [...]", escreve ele em 17 de novembro, "[...] repetir o ritmo do texto com os atores até que eles o absorvam". O impedimento de assistir aos ensaios leva Novarina a radicalizar o seu discurso e a reiterar com força o que será a marca da sua poética teatral: o ritmo, a deglutição do texto e a somatizaçáo da linguagem.

Essa obsessão reaparece em 21 de novembro, quando, após uma negociação, ele adquire "o direito de olhar, de entrada livre". Ele anota, entáo: 
[...] é imprescindível que eu faça um trabalho sobre o ritmo: com um ou dois atores, fora da encenação; com o conjunto (por intermédio de J.-P). Objetivo imediato: leitura feita por mim da segunda parte; ensaios com os atores sobre o texto. Conseguir isso. Mas eu estou pisando em ovos.

No dia 23 de novembro ele resume os seus objetivos em uma só frase: "afinal, perguntar a cada ator o que ele quer de mim", e ele diagnostica, em 28 de novembro, o ponto nodal do conflito: "nós nos encontramos diante de um processo muitíssimo violento de identificação ao texto com rejeição muito forte do autor como pessoa exterior, excedente". Ao longo dos ensaios, a situação se tensiona ainda mais, dessa vez com os próprios atores. Novarina faz um relato detalhado, anotando escrupulosamente as manipulações, cortes, frustrações, dificuldades em chegar a um acordo. Ele admite: "eu faço um esforço hercúleo para nada" (4 de dezembro), ele consegue, no entanto, após ter escolhido uma "presença em eclipse durante os ensaios" (6 de dezembro), definir suas relaçóes com Jean-Pierre Sarrazac como "ultra diplomáticas e afetuosas" (4 de dezembro). Retrospectivamente, Novarina reconhecerá os inegáveis méritos de uma encenação que, segundo suas próprias palavras, tinha "[...] vinte anos de antecedência surpreendendo as normas de uma época congelada".

Nesses episódios de criação cênica de múltiplas reviravoltas, Novarina toma, dolorosamente, consciência de que a escrita teatral se dá na verdade dos corpos e no corpo da linguagem. Suas anotaçóes cotidianas fazem valer essa ideia. Ademais, quando sabemos o interesse meticuloso que ele ainda tem pelo ritmo conjugado ao tempo e aos espaços, pelos exercícios de descoberta das palavras e pela necessidade de não ficar preso ao enredo, nós compreendemos melhor a sua frustração em ver uma boa parte das decisóes estéticas lhe escaparem. Em uma entrevista concedida a um número da revista Europe, quando interrogado por Céline Hersant (2002, p. 118) sobre a sua encenação de L'Atelier Volant, Jean-Pierre Sarrazac, admitindo, ele também, as tensóes, explica o mal estar de Novarina pelo contexto sociopolítico da época: "[...] nós estávamos em meio ao teatro do enredo, pós ou 'neo-brechtiano', e a dimensão cômica, até mesmo grotesca, a oralidade, a extrema qualidade poética da escrita de Valère escapavam a muitos"16. A explicação é parcial, mas justa. No universo teatral dos anos 1970, o texto e a encenaçáo, tal qual pensa Novarina, estáo desnivelados em relaçáo às certezas adquiridas: 
eles oferecem uma outra zona de visibilidade e de entendimento que o feixe de energia dos atores investirá pouco a pouco à contracorrente. Isso é o que Novarina exprime no fogo dessa primeira criação por intermédio de uma fórmula lapidária cujo sentido, virgem de comprometimento, ficará presente posteriormente: “[...] eu quero ter a carne viva, não de uma marionete; eu quero ter intensidade, não intençóes" (8 de dezembro).

Todos esses atos de encenamento chegam finalmente a um fim provisório na sexta-feira, 25 de janeiro de 1974, dia da primeira apresentação na sala Jean Vilar de Suresnes.

\section{Fabrica Volatilis... Officina mobilis}

A estreia do espetáculo, entretanto, não é o ponto culminante. Ela não resolve nada, ao menos aparentemente: as relações continuam a ficar tensas, "obscura aventura", anota Novarina (26 de janeiro), "violência extrema. O grupo une-se novamente" (28 de janeiro); após o estudo de uma série de mudanças possíveis: "crise total" (31 de janeiro). Finalmente, na terceira apresentação na complicada sala Jean Vilar de Suresnes, "a crise, a angústia dos atores viram-se em favor do espetáculo; despertar dos atores [...]. O espetáculo todo na máo dos atores" (31 de janeiro) "O espetáculo avança", observa Novarina em 1 de fevereiro e, entretanto, em 3 de fevereiro "fiasco e fracasso total". De 7 a 9 de janeiro, com "muito pouca gente" na plateia, as coisas vão um pouco melhor. A última apresentação foi no domingo, 10 de fevereiro, antes da ida da trupe a Lyon, onde encontram, desde a estreia, no dia 19 de fevereiro, até 2 de março, condiçóes melhores do que em Paris, um público melhor, mas ainda com altos e baixos e oscilaçóes de comportamento dos atores ${ }^{17}$.

"Eu vivo tudo isso como um maio de 68. Uma crise. Um embaralhar de cartas. Uma ocasiáo raramente dada de poder repensar tudo", anotou Novarina em 26 de novembro de 1973. Alguns dias antes, em 23 de novembro, nesse mesmo estado de espírito, ele tirava dessa experiência não somente as qualidades esperadas em uma peça em busca da sua forma singular, mas, mais amplamente, certa poética programada para o futuro:

[...] eu vejo a situação com bastante clareza. Do ponto de vista dos corpos, das paixóes. Enquanto J.-P. (Jean-Pierre Sarrazac) vê isso como um empreendimento, uma construção pedra sobre pedra. Parece-me que o espetáculo é 
o resultado de dois meses de luta (autor-diretor-atores-orçamentos). São os corpos que estão em jogo [...]. Dez dias depois do primeiro ensaio, eu tenho clareza no que toca a minha relaçáo com o teatro e a minha relaçáo com o ator ${ }^{18}$.

$\mathrm{O}$ aspecto iniciático dessa experiência fundadora é, aqui, claramente reivindicado. Esse fato também não havia escapado ao outro protagonista da aventura, J.-P. Sarrazac, que afirmaria, quase 30 anos mais tarde:

[...] era isso L'Atelier Volant. Eu acho que Valère inventou, a partir de L'Atelier Volant, alguma coisa que poderíamos chamar de o teatro ininterrupto [...]. E eu me pergunto se L'Atelier Volant, que é ainda uma peça de execuçáo bastante clássica, não é justamente a única que Novarina teria escrito e que continuaria a escrever no decorrer da sua obra (entrevista em Hersant, 2002, p. 122-123)

Ao ler esse Diário que, assim como muitos manuscritos preparatórios do teatro, deixa vestígios cujos contextos e dados estáo muitas vezes perdidos, nós podemos, amenizando os propósitos, afirmar que, nas tensóes entre os dois polos que se atraíram e se repeliram, o escritor-dramaturgo encontrou sua estratégia de escrita. Doravante, para ele, o palco participará diretamente do ato da escrita, daí a necessidade de encenar o maior número de vezes possível as suas próprias obras, nessa busca infinita que apaga fronteiras entre as superfícies conjuntas da página e da cena. Ele parece procurar um espaço que preencheria suas expectativas do absoluto teatral. "O espaço me excita", ele confessa em 9 de junho de 1978, em uma anotação acrescida posteriormente.

Quanto à noção de "teatro ininterrupto", complementar à constatação precedente, ela também se afirma muito lúcida e muito cedo. Novarina propóe, assim, em 6 de julho de 1978, dar como subtítulo ao Drame dans la langue française: "ação perpétua". A fórmula fala por ela mesma: para ele, na elaboraçâo de uma obra estranha às categorias genéricas, trata-se menos de fazer com que uma peça seja sucedida por outra do que criar uma peça a partir de outra, em uma cadeia ininterrupta de gêneses sucessivas. A tarefa proposta aos geneticistas segue, portanto, novas regras, ela torna-se mais árdua e, por vezes, quase desesperada ${ }^{20} \mathrm{com}$ a pulsão criativa que faz com que se sobreponham diversos planos, sem que se possa distinguir, nesses estratos acumulados por tantos anos, as antigas falhas dos novos caminhos de montes e atalhos. Ela se limita ainda, por vezes, 
nesses territórios imprecisos, apenas a juntar fragmentos entre si. Entretanto, a transtextualidade, apesar das alteraçóes e constantes modificações, ganha sentido nessa mistura; não é indiferente, por exemplo, saber que é no meio do tumulto dos ensaios de L'Atelier Volant que Novarina dá continuidade à escrita de Babil des Classes Dangereuses. Em 29 de abril de 1972, ele anota sobre esse assunto: "estranhamente, isso começa a tomar forma". Uma experiência de escrita e de criação cênica nutre o outro e se nutre do outro. Alguns anos mais tarde, ele anotará ainda, em 21 de junho de 1976, provavelmente lembrando-se de L'Atelier Volant: "No dia em que Babil for encenado (se for encenado) lembre-se bem de que: só se produz aquilo que é pesado".

Compreendemos que essa postura, em que um tal conjunto de texto/encenação leva sempre a uma próxima criação à frente, recusa, numa dinâmica permanente de reapropriaçáo, o caminho da inteligibilidade imediata. Correr-se-ia, de fato, o risco de petrificar o sentido pela mediação de um diretor que ignora as mobilidades internas e as surpresas do aleatório de uma obra em contínuo andamento. A obra por inteiro, desde o impulso inicial, que foi L'Atelier Volant, se mostra, assim, como um conjunto em movimento e como um enigma (uma carta enigmática, diria hoje Novarina). Todavia, como na questáo da Esfinge, o homem continua sendo o tema do enigma. No momento em que ele dá início ao seu Diário, em janeiro de 1972, antes mesmo da lista de atores qualificados para L'Atelier Volant, Novarina escreve, fazendo eco ao título da obra, esta frase em forma de epígrafe: "fabrica volatilis...officina mobilis". Provavelmente as palavras-chave de toda a sua criaçáo. 


\section{Notas}

${ }^{1}$ Este texto é uma versão revisada traduzida do original em francês publicado em THOMASSEAU, Jean-Marie. Un Journal de Genèse, L’Atelier Volant de Valère Novarina. Revue d'Histoire du Théâtre, Paris, Société d'Histoire du Théâtre, n. 249, p. 93-104, 2011.

${ }^{2}$ Toda a minha gratidáo vai para Valère Novarina que, muito generosamente, colocou à minha disposição este diário íntimo, além de diversos outros documentos (correspondências, versóes sucessivas, documentos diversos, entre os quais um Caderno de anotaçóes para a encenação de La Fuite de Bouche) que acompanharam a criação e os ensaios de retomada de L'Atelier Volant. O manuscrito sobre o qual se apoia este estudo é apresentado sob a forma de um registro, revestido de uma capa dura de cor preta, formato $18,5 \mathrm{~cm}$ x $30 \mathrm{~cm}$, tal qual os cadernos utilizados por comerciantes antes do advento dos computadores. As páginas são quadriculadas e numeradas de 1 a 299. O texto do autor, escrito em caneta-tinteiro, com letras bem estreitas, mas legíveis, começa bem no alto da página 1, na data de janeiro de 1972 e termina com dias, às vezes semanas e, mais para o fim, longos anos de interrupçáo, na página 106, em 29 de setembro de 2000, com uma última anotação. As páginas que tratam explicitamente da escrita e da encenação de L'Atelier Volant estão, na maior parte, nas páginas 1 (17 de janeiro de 1972) a 48, que trata, em 4 de janeiro de 1978, da estreia de La Fuite de Bouche em Marselha. No texto e nas notas, as referências a esse documento serão assinaladas como Diário. Anotaremos, para cada citação, a data em que foi escrito: as mudanças de ano serão assinaladas na primeira citaçáo do ano em questão.

${ }^{3}$ O leitor poderá consultar o texto mencionado sob o título: Les manuscrits du théâtre na revista Littérature, n. 138, junho de 2005, p. 97-118. Sobre a questão mais geral da genética teatral e suas questóes, ele poderá examinar em: Almuth Grésillon; Jean-Marie Thomasseau, "Scènes de genèse théâtrale", Genesis, n. 26, Imec / Jean-Michel Place, 2005, p. 19-34.

${ }^{4}$ Em um rascunho de carta sem data (1968) a Jean-Marie (Villegier), no qual trata de uma visita aos médicos militares, Novarina diz ter pensado no seguinte título: Monsieur Budet montre ses employés sur le théâtre. A primeira versão de L'Atelier Volant tinha realmente esse título: um dossiê dos arquivos de Novarina é inteiramente consagrado a isso. $\mathrm{Na}$ capa, escritas à mão pelo autor, estão as seguintes datas: 1966-1968 M. Budet/1968-1970 L'Atelier Volant. Monsieur Budet [...] foi entregue para leitura a Bernard Dort, primeiro leitor histórico de Novarina.

${ }^{5}$ A carta de Roland Barthes é datada de 3 de maio (1969): "[...] eu encontro com o maior remorso que você deve imaginar o texto que você me enviou em dezembro. [...] eu fiquei impressionado com a melhora extraordinária do seu texto: é duro, cheio de uma fantasia incisiva extremamente saborosa: inteiramente enxugado e muito engraçado. Parece-me que ele é possível de ser montado”. Novarina tinha enviado seu texto também a Michel Deguy, Roger Blin, Jean-Marie Villegier. Uma carta de Malik Aissaoui, dramaturgo argelino, datada de 19 de novembro de 1969 e dirigida a Novarina confirma: "Monnaie de Bouc. Roland Barthes. Ele leu a peça, mas rapidamente como eu lhe havia dito, ele estava viajando. Isto é o que ele me disse: a linguagem e a forma são ousadas [...] há uma faceta de teatro de marionetes [...]. Eu compreendo a sua vontade de montar a peça". Nessa correspondência em torno de L'Atelier Volant figura, ainda, uma breve, mas pertinente 
análise, não datada, de François Regnault, da qual poderíamos retirar as seguintes linhas: "peça, salvo o leitor (eu), que se inquieta com dois Caríbdis em uma navegação tão rabelaisiana. Uma delas de caráter cômico, na qual - raramente é verdade - mais de um ator sucumbirá durante a encenação, partindo mais de um espectador, no momento em que, capturado por uma réplica claramente alusiva, reconhecerá, sem a complacência do riso, sua íntima TV, seu sabonete, seu chapéu de praia. A outra, da própria escrita, mais Sula do que Caríbdis, me faz preferir as implacáveis dialéticas das primeiras cenas (da primeira parte), em que o alerta se adéqua ao demonstrado, aos foguetes que, sobretudo, se multiplicam, se contagiando, se explodindo uns aos outros quando o esplendor das girândolas e as peças pirotécnicas cai em confetes obscuros, confunde a língua e a linguagem e substitui o desvio pelo delírio, o casal protetor pelo louco, e no que diz respeito ao autor, o analista precioso pelo talentoso intempestivo".

${ }^{6}$ N. T.: essa expressão francesa refere-se ao trabalho e exercício da voz no âmbito do espetáculo.

${ }^{7}$ Nessa data, uma pré-publicação do texto de L'Atelier Volant havia saído no Travail thêatral, n. 5, outono de 1971, p. 46-87.

${ }^{8}$ A estreia de L'Atelier Volant aconteceu na sexta-feira, 25 de janeiro de 1974, no teatro Jean Vilar de Suresnes, a última apresentação, após dez exibiçôes, foi no domingo, 10 de fevereiro (Diário, 25 de janeiro - 10 de fevereiro). Os atores, nove no total, foram escolhidos conjuntamente por Valère Novarina e Jean-Pierre Sarrazac; tratava-se de Françoise Beliard, Monette Berthommier, Michel Berto, Arlette Bonnard, Sylvie Curtenaz, Stéphane Kosiak, François Kuki, Bernard Meulien e Alain Ollivier. O pintor Gauvin, que deveria colaborar mais tarde como cenógrafo em Drame de la vie e em Vous qui habitez le temps, era responsável pelo cenário e pelo figurino. Com o título - La Fuite de Bouche - em uma encenação de Bernard Ballet (cenário e figurino de Jacques Angeniol) e com algumas modificaçóes, a obra é encenada no Teatro Nacional de Marselha, em 1978 (a estreia foi em 4 de janeiro) e depois publicada com esse título pela editora Jeanne Laffitte (coleção Approches "Répertoire", n. 1, $1^{\circ}$ trimestre de 1978). Na edição do Théâtre, da editora P.O.L., em 1989, a peça retoma o seu título original: L'Atelier Volant. O Diário ainda faz referência a uma apresentaçáo na Maison des Arts de Thonon, em 5 de março de 1974 e no Grenier de Toulouse. Após uma apresentação da obra diante dos "representantes do público", a direçáo decide anular as apresentaçóes seguintes sem advertir Novarina (16 de março de 1974).

${ }^{9}$ Lettre aux Acteurs teve duas pré-publicaçóes parciais, em 1976, sob o título de Lettre aux Acteurs de l'Atelier Volant, em Approches, Marselha, fevereiro de 1976, p. 5 e em Ça, cinéma , Ed. Albatros, n. 9, p. 88-96. A primeira versão definitiva foi publicada em Argo, n. 26, Lausanne, 10 de janeiro de 1979. Essa mesma versão seria publicada em março do mesmo ano nas ediçóes Énergumène.

${ }^{10}$ Essas anotaçóes acompanham um projeto com uma gravação de quarenta minutos, intitulado Action du trou de science, que deveria se desenrolar nas ruínas de Ris Orangis, mas não pode ser apresentado por conta da proibição oficial da representação nas ruínas. A performance foi proposta ao museu de ciências de Miláo, em 25 de novembro de 1978, durante um colóquio, em péssimas condiçóes técnicas. Novarina realizaria parcialmente esse desejo em 2007, em Avignon, em sua exposição na Capela do Milagre. 
${ }^{11}$ Grifo nosso.

${ }^{12}$ Uma carta de Novarina a Christian (Prigent), de 25 de setembro de 1980, cujo rascunho está inserido no Diário esclarece em parte a função da leitura no desen rolar da obra: "[...] as leituras públicas só fazem sentido para mim se forem esgotantes. Que elas sejam realmente desgastantes, uma doação [...]. Eu decidi há muito tempo só fazê-las quando eu sentir necessidade".

${ }^{13}$ A distribuição definitivamente fixada em 25 de janeiro de 1972 incluía, segundo o Diário: "Maréchal, Ts(illa) Chelton, Bolo [...] Jean Martin, (René-Jean) Chauffard, Denis Manuel et [...] Bérangère Dautun, Colette Berger, Rosy Varte".

${ }^{14}$ As páginas 4 a 8 do Diário, que váo de 8 de fevereiro 1972 à 3 de junho de 1972 tratam, entre outros assuntos, dos detalhes desses episódios sem que tenha sido possível ao leitor desemaranhar todos os fios. Carta de Marcel Maréchal à Valère Novarina, de 17 de setembro de 1971: "me pediram para apresentar à France-Culture 3 textos que eu goste particularmente. Eu pensei na sua peça, é claro, para uma das três noites" (correspondência sobre L'Atelier Volant).

${ }^{15}$ Uma carta de Malik Aissaoui em resposta à Novarina, o qual tinha lhe enviado seus textos, nos fala sobre a natureza das duas primeiras versóes de L'Atelier Volant, ambas intituladas Monnaie de Bouc (um primeiro título, Monnaie de Singe, parece ter sido cogitado por Novarina em uma carta do mesmo correspondente em 18 de abril de 1969) para as quais ele sugere alteraçóes (carta de 25 de junho de 1969). Malik Aissaoui propóe, ainda, a Novarina, em uma carta de 24 de fevereiro de 1970, incluída em uma correspondência intensa, um projeto detalhado de encenação para apresentaçôes em Paris, projeto no qual, como na carta anterior, ele insiste no ritmo. Uma carta de 15 de abril sugere uma mudança de título; outra, de 6 de outubro, fala sobre L'Atelier Volant. O título foi claramente mudado entre essas duas datas (correspondência sobre L'Atelier Volant). Hoje, Novarina fala de uma verdadeira "crise do título" e de um título escolhido em extrema urgência.

16 "L'Atelier Volant ou le théâtre de l'origine", in Europe, "Valère Novarina", agosto-setembro de 2002, n. 880-881, p. 118. Sobre as tensóes entre o autor e o diretor, Jean-Pierre Sarrazac escreve ainda: "[...] houve conflitos, tensôes, nove atores para dirigir, e eu era um diretor muito novo; mas eu tinha fé absoluta, um entendimento sobre muitas coisas com Valère, especialmente no gestual" (Hersant, 2002). O fato da originalidade teatral de Novarina náo ser percebida é evidenciado na resposta feita pelo punho de Luc de Goustine pela editora Seuil no envio do texto de L'Atelier Volant: “[...] o seu Atelier Volant nos interessou bastante. Talento e gosto na invenção verbal, um senso musical real e algumas situaçóes dramáticas fortes, pertinentes nas suas sátiras, libertadoras na profusão dos grotescos. Nossas objeções: a linguagem e seus prazeres transbordam e sufocam muitas vezes a ação dramática sobre a qual deveria se articular à história? [...] eu sugiro que você defina melhor o enredo e torne a economia de linguagem mais eficaz" (correspondência sobre L'Atelier Volant - Carta de 6 de agosto de 1971).

${ }^{17} \mathrm{O}$ primeiro rastro da Lettre aux Acteurs aparece no Diário na data do 2 de dezembro de 1973: "eu datilografo espontaneamente algumas anotaçóes para os atores sobre a 'respiraçáo'[...]. Primeira experiência de escrita 'no fluxo' para esse tipo de texto [...]”. No 
Caderno de anotaçóes para a encenação de La Fuite de Bouche, em 1978, nós encontramos esta insólita anotação: "Lettre aux Acteurs - intitulá-la La feuille de Rose /La Fuite de Bouche seguida de La Feuille de Rose, aos atores". Em outro dossiê de título: "anotaçóes para a encenaçáo de L'Atelier Volant" (dezembro de 1973) composto alternadamente de textos datilografados e manuscritos, encontramos as seguintes reflexóes: "[...] o que podemos dizer ao ator além de vá lá? [...] que os atores contem os seus corpos, todos eles escrevem os seus sonhos, é preciso que eles contem, nada avançará na teoria teatral a não ser através dos relatos dos atores (as assembleias do teatro deveriam ter sido dedicadas apenas a isso, ao invés do que fizeram os diretores, que vieram nos falar de corpo não-presente, do nãopúblico".

${ }^{18}$ Essas representações lionesas deram espaço à única crítica positiva e visionária, graças às palavras de Jean-Jacques Lerrant em Le Progès, de 22 de fevereiro de 1974: "[...] ouçamos este verbo suculento com suas extravagâncias excêntricas, suas tiradas que libertam fontes, tiradas estranhas porque nelas a lógica perde suas pedras brancas, mas nas quais adivinhamos, por vezes repentinamente, arquiteturas subterrâneas. Aí está realmente um autor. Jean-Pierre Sarrazac, diretor, o exibe e o serve, através de movimentos e piadas muito bem elaborados que questionam constantemente o próprio jogo, forçando-o a se inventar em uma irrealidade que é a realidade teatral mais colorida”.

${ }^{19}$ Hersant, 2002 in Europe, p. 122-123.

${ }^{20}$ A tentativa foi feita por Céline Hersant, que utiliza na sua tese a noção de "reciclagem": Recyclage et fabrique continue du texte, Valère Novarina, Noëlle Renaude, Daniel Lemahieu, Thèse, Paris III (org. J.-P; Sarrazac), 2006.

\section{Referências}

GRÉSILLON, Almuth; THOMASSEAU, Jean-Marie. Scènes de Genèse Théâtrale. Genesis, Imec/Jean-Michel Place, n. 26, p. 19-34, 2005.

HERSANT, Céline. L'Atelier volant ou le théâtre de l'origine. Entrevista com Jean-Pierre Sarrazac. Europe, n. 880-881, p. 117-125, ago./set. 2002.

HERSANT, Céline. Recyclage et Fabrique Continue du Texte: Valère Novarina, Noëlle Renaude, Daniel Lemahieu. 2006. Tese (Doutorado em Etudes Théâtrales) - Université de la Sorbonne Nouvelle, Paris III, 2006.

NOVARINA, Valère. L’Atelier Volant. Travail Thêatral, n. 5, p. 46-87, out./dez. 1971.

NOVARINA, Valère. La Fuite de Bouche. Marseille: Jeanne Laffitte, 1978. (coleção Approches Répertoire, n. 1).

NOVARINA, Valère. Lettre aux Acteurs de l'Atelier Volant. Marseille: Jeanne Laffitte, 1976.

NOVARINA, Valère. Lettre aux Acteurs. Argo, Lausanne, n. 26, jan. 1979.

THOMASSEAU, Jean-Marie. Les Manuscrits du Théâtre. Essai de Typologie. Littérature, Paris, n. 138, p. 97-118, jun. 2005. 
THOMASSEAU, Jean-Marie. Un Journal de Genèse, L'Atelier Volant de Valère Novarina. Revue d'Histoire du Théâtre, Paris, Société d'Histoire du Théâtre, n. 249, p. 93-104, 2011.

Jean-Marie Thomasseau é professor emérito da Université Paris 8 Vincennes Saint Denis, na França. É um dos pioneiros da Genética Teatral e possui diversas publicaçóes na França e no exterior, inclusive no Brasil.

E-mail: decursay@hotmail.com

Traduzido do original em francês por Luana Franco Rocha (Universidade Federal Fluminense) sob a supervisão de Dominique M. P. G. Boxus (Universidade Federal Fluminense). Revisado por André Mubarack.

Recebido em 08 de dezembro de 2012 Aprovado em 17 de março de 2013 